\title{
Assessment of Heavy Metal Pollution and Potential Ecological Risk in Sewage Sludge from Municipal Wastewater Treatment Plant Located in the Most Industrialized Region in Poland-Case Study
}

\author{
Malwina Tytła \\ Institute of Environmental Engineering, Polish Academy of Sciences, 34 M. Skłodowskiej-Curie St., \\ 41-819 Zabrze, Poland; malwina.tytla@ipis.zabrze.pl
}

Received: 13 June 2019; Accepted: 6 July 2019; Published: 9 July 2019

\begin{abstract}
This study aimed to assess the pollution and potential ecological risk of seven heavy metals $(\mathrm{Cd}, \mathrm{Cr}, \mathrm{Cu}, \mathrm{Hg}, \mathrm{Ni}, \mathrm{Pb}$, and $\mathrm{Zn})$ in the sewage sludge collected from a wastewater treatment plant (WWTP), located in the most industrialized region of Poland (Silesian Voivodeship). The concentrations of heavy metals were determined using inductively coupled plasma optical spectrometry (ICP-OES) and cold vapor atomic absorption spectrometry (CVAAS). The chemical forms (chemical speciation) of heavy metals were determined using the three-step chemical sequential extraction procedure, developed by the Community Bureau of Reference (BCR). To assess the pollution level and potential ecological risk, the following indices were used: Geoaccumulation Index ( $\left.\mathrm{I}_{\text {geo }}\right)$, Potential Ecological Risk Factor (ER), Individual Contamination Factor (ICF), Risk Assessment Code (RAC), and Ecological Risk Factor (ERF)—the author's index. Sludge samples were collected at successive stages of processing. The results revealed that the activated sludge process and sludge thickening have a significant impact on heavy metal distribution, while anaerobic digestion and dehydration decrease their mobility. The most dominant metals in the sludge samples were $\mathrm{Zn}$ and $\mathrm{Cu}$. However, the content of heavy metals in sewage sludge did not exceed the permissible standards for agricultural purposes. The concentrations of heavy metals bound to the immobile fractions exhibited higher concentrations, compared to those bound to mobile fractions (except $\mathrm{Zn}$ ). The values of the total indices indicated that sludge samples were moderately to highly contaminated with $\mathrm{Zn}$, $\mathrm{Hg}, \mathrm{Cd}, \mathrm{Cu}$, and $\mathrm{Pb}$, of which only $\mathrm{Hg}$, $\mathrm{Cd}$, and $\mathrm{Cu}$ posed a potential ecological risk, while according to the speciation indices, sludge samples were moderately to very highly polluted with $\mathrm{Zn}, \mathrm{Cu}, \mathrm{Cd}$, $\mathrm{Cr}$, and $\mathrm{Ni}$, of which $\mathrm{Zn}, \mathrm{Ni}$, and $\mathrm{Cd}$ were environmentally hazardous. The obtained results proved that assessment of the pollution level and potential ecological risk of heavy metals in sewage sludge requires knowledge on both their total concentrations and their chemical forms. Such an approach will help prevent secondary pollution of soils with heavy metals, which may influence the reduction of health risks associated with the consumption of plants characterized by a high metal content.
\end{abstract}

Keywords: heavy metal pollution; ecological risk assessment; chemical sequential extraction; sewage sludge; wastewater treatment plant; Silesian Voivodeship

\section{Introduction}

Sewage sludge is a waste organic material generated in wastewater treatment plants (WWTPs), as a by-product of wastewater treatment $[1,2]$. Therefore, the final quality of sludge mainly depends on the chemical composition of raw wastewater and processes used in the WWTPs. The production of sewage sludge increases every year, which results from population growth and the increasing effectiveness of biological wastewater treatment processes [3-5]. It is indicated in the literature that by 
2020 the total production of sewage sludge in European Union (EU) countries will reach 12,997,000 tons of dry matter (DM), of which 950,000 tons will be generated in Poland (Central Europe) [6].

Sewage sludge is composed of high concentrations of organic matter (OM) and biogenic compounds, especially nitrogen $(\mathrm{N})$ and phosphorus $(\mathrm{P})$, which are necessary for plant growth $[1,2,7]$. However, it also contains heavy metals, including those classified as toxic, i.e., cadmium $(\mathrm{Cd})$, chromium $(\mathrm{Cr})$, copper $(\mathrm{Cu})$, mercury $(\mathrm{Hg})$, nickel $(\mathrm{Ni})$, lead $(\mathrm{Pb})$ and zinc $(\mathrm{Zn})[8,9]$. This means that, depending on the concentration and exposure time, a given metal can pose both environmental and health risks, which is associated with its ability to bioaccumulate in the food chain [10]. The most common sources of heavy metals in sewage sludge are domestic and industrial wastewaters and corrosion of sewerage systems, as well as surface runoff from urbanized areas or roads [11,12]. WWTPs may also receive wastewater from the agro-industrial sector. Other sources of heavy metals are pharmaceuticals, as well asbody care and cleaning products. Moreover, illegal wastewater discharges are also an important source of sewage sludge pollution with heavy metals [13].

Heavy metals present in the influent wastewater accumulate in sewage sludge (approximately 80-90\%), which may affect its treatment and final characteristics [14]. Unfortunately, processes commonly used in WWTPs do not definitely guarantee the removal of heavy metals, which in turn can lead to secondary environmental pollution [10]. Therefore, the effective protection of the natural environment against pollution from sewage sludge is of great concern nowadays. Even more important, is having regard for the fact that the most preferable method for sludge management is its use as a fertilizer or substrate for soil remediation $[3,8]$. In the EU countries, from $30 \%$ to $50 \%$ of sewage sludge is used in agriculture, which constitutes an alternative to landfill or incineration $[4,7]$. In Poland, one of the most important criteria for agricultural use of sludge is heavy metal concentrations; for which limits are regulated by the Regulation of the Minister of Environment of 13 July 2010 on municipal sewage sludge (J. L. 2010, No. 137, item. 924) [15], being compatible with the Council Directive of 12 June 1986 on the protection of the environment, and in particular of the soil, when sewage sludge is used in agriculture (86/278/EEC) [16]. It is worth noting that high concentrations of heavy metals in sewage sludge may cause contamination of soil, and surface and ground water as well as crops, and as a consequence, have a negative impact on living organisms, including animals and humans [3]. However, knowledge of the total concentrations of heavy metals allows only for the assessment of the degree of sludge pollution and is inconclusive regarding the potential ecological risk that these elements may pose to the environment and living organisms. This is due to the fact that the mobility, bioavailability, and toxicity of heavy metals depend on their speciation forms (in this case the chemical), which are influenced by their leaching and interactions with different components of natural ecosystems $[2,17,18]$. The most commonly used method to determine the chemical forms of heavy metals in sewage sludge, is the three-step chemical sequential extraction procedure proposed by the Community Bureau of Reference (BCR; now the Standards, Measurements and Testing Programme) [17,19-21], which is a modification of the Tessier method [22]. It is worth mentioning that every change in environmental conditions, such as $\mathrm{pH}$ value, redox potential (Eh), organic matter content (OM), etc., results in changes to the mobility of metals and thereby, in their bioavailability [4]. Moreover, heavy metals bound to the sludge structure, can also undergo transformation while being subjected to the biological, chemical, and mechanical processes used in WWTPs [8]. Therefore, it is important to analyze not only total concentrations but also chemical forms, during various stages of sludge processing. This approach results in more precise assessment of the potential ecological risk posed by these elements. So far, there are not many publications in this research area in the scientific literature and these works are mostly devoted to one selected type of sludge, i.e., dewatered $[17,21]$. However, the approach presented in this study allows a more comprehensive analysis of the ecological risk to be conducted, which includes sludge characteristics for the whole technological line of the WWTP.

A variety of methods have been proposed in order to assess the pollution level and ecological risk of heavy metals in sewage sludge. In this study two different types of indices were used, i.e., total content indices and speciation indices [23]. The first group, total content, comprised the Geoaccumulation Index 
(Igeo) [24] and Potential Ecological Risk Factor (ER) [25], whereas the second group, speciation indices, comprised the Individual Contamination Factor (ICF) [23,26], Risk Assessment Code (RAC) [27], and Ecological Risk Factor (ERF) - the author's index. These indices are calculated in different ways and include various aspects. For example, $I_{\text {geo }}$ considers the accumulation level of heavy metals in sewage sludge, without toxicity impact; ER focuses both on the total quantity of heavy metals and toxicity; while ICF, RAC, and ERF focus on heavy metal mobility [11]. In previous years, the above-mentioned indices have been successfully used to assess the ecological risk in soils and sediments $[28,29]$.

The Silesian Voivodeship is one of the most urbanized areas in Poland and the largest industrial region in the country. The diversity of the industrial sector in this region, e.g. metallurgical coal, mining, energy production, heavy industry, and transportation, contributes to the environmental pollution with heavy metals $[30,31]$, which in turn, has an impact on the chemical composition of wastewater discharged into WWTPs, and as a consequence, on the characteristics of sewage sludge. In 2017, the production of sewage sludge in the Silesian Voivodeship reached 64,039 tons of DM, of which 10,317 tons were used for agricultural purposes [32]. Thus, both the geographical location of the studied WWTP, as well as the presence of heavy industry and strong environmental pollution by heavy metals in this area, provided legitimacy for carrying out this research.

The aims of this study were: (1) to determine the total concentrations of heavy metals $(\mathrm{Cd}, \mathrm{Cr}, \mathrm{Cu}$, $\mathrm{Hg}, \mathrm{Ni}, \mathrm{Pb}$, and $\mathrm{Zn}$ ) in sewage sludge at different processing stages; (2) to investigate the chemical forms of heavy metals in sewage sludge by using the BCR sequential extraction procedure; and (3) to assess the pollution level and potential ecological risk of heavy metals in sewage sludge.

\section{Materials and Methods}

\subsection{Study Area and Sampling}

The sewage sludge samples were collected in October 2018 from the municipal "Central" wastewater treatment plant in Bytom, Silesian Voivodeship, Southern Poland (Central Europe). The WWTP is located in the most important industrial region in Poland (Figure 1). Examples of industrial activities in the Silesian Voivodeship are shown in Figure 2.

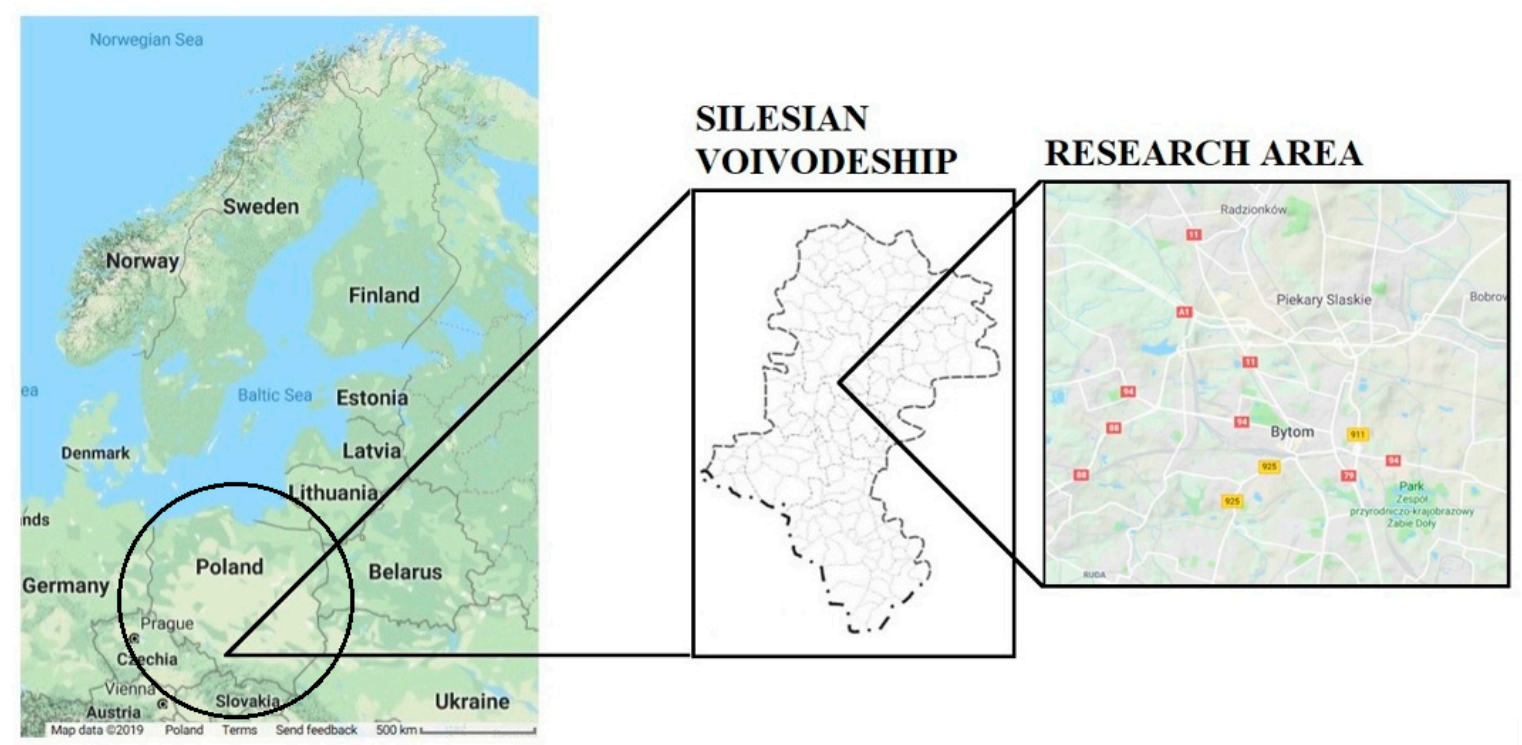

Figure 1. The maps present the location of study area. Original source files from: https://www. google.pl/maps/@52.0122001,29.5346949,3.17z/data=!5m1!1e4?hl=en; https://www.google.pl/maps/@50. $3650717,18.80662,12 \mathrm{z} /$ data $=! 5 \mathrm{~m} 1 ! 1 \mathrm{e} 4$ ?hl=enfgg [33,34].

Sludge samples were collected twice, at 1-hour intervals, at seven sampling points constituting stages in the technological line of the WWTP: primary sludge-from settling tank (S1), primary 
sludge—after thickening (S2), secondary sludge—from settling tank/after activated sludge process (S3), secondary sludge - after thickening with addition of conditioning agent (S4), mixed sludge-from sampling point numbers 2 and 4 (S5), digested sludge-from anaerobic digester (S6), and dewatered sludge from belt press (S7). This approach was intended to capture changes in the physicochemical characteristic of sludge at different stages of processing, and to obtain the most representative samples. All samples were kept in polypropylene containers and stored in a refrigerator at $4{ }^{\circ} \mathrm{C}$, until analysis. The operational parameters of the WWTP are shown in Table 1.

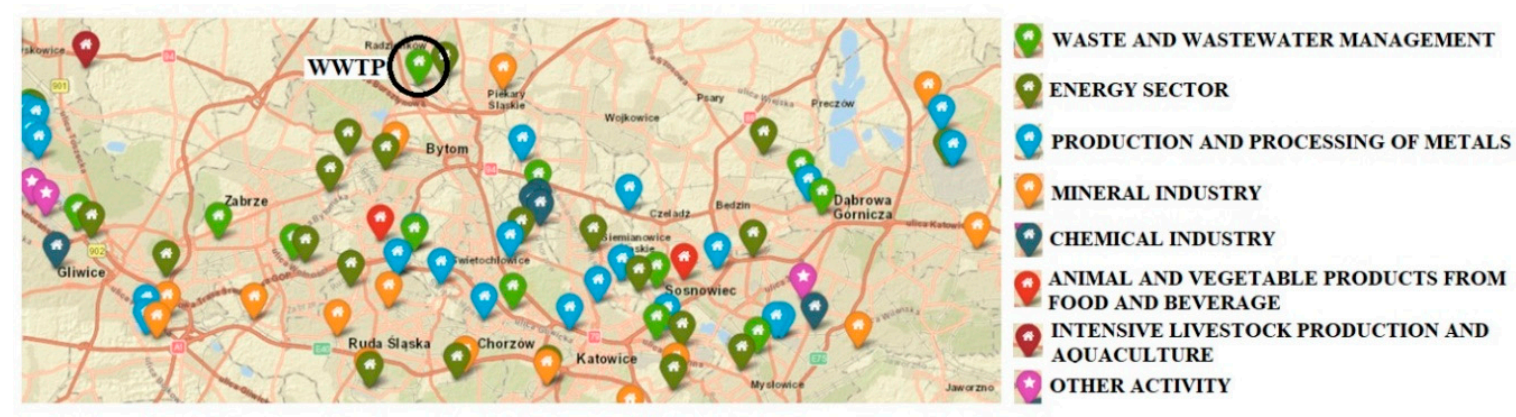

Figure 2. Industrial activity in the Silesian Voivodeship. The map presents a fragment of the largest industrial region in Poland (with "Central" wastewater treatment plant (WWTP) in Bytom marked). Original source files from: https://prtr.eea.europa.eu/\#/industrialactivity [35].

Table 1. The operational parameters of the WWTP.

\begin{tabular}{ccc}
\hline Parameter & Unit & Value \\
\hline Population equivalent (PE) & - & 143,368 \\
Average flow (Q) & $\mathrm{m}^{3} \cdot \mathrm{d}^{-1}$ & 19,330 \\
Hydraulic retention time (HRT) of sludge in anaerobic digester & $\mathrm{d}$ & 21 \\
Temperature in the anaerobic digester & ${ }^{\circ} \mathrm{C}$ & 36 \\
\hline
\end{tabular}

Data for the year 2017 obtained from the "Central" WWTP in Bytom.

\subsection{Physicochemical Analysis}

\subsubsection{Measurement of $\mathrm{pH}$, Redox Potential (Eh), Dry Matter (DM) and Organic Matter (OM)}

The $\mathrm{pH}$ and Eh of sewage sludge were measured using a multifunctional meter CPR-411 (Elmetron) and electrodes as in order: IJ44A (Elmetron) and ERS-2 (Elmetron). The content of DM and OM in sewage sludge was determined after drying at $105^{\circ} \mathrm{C}$ and then ignition at $550{ }^{\circ} \mathrm{C}$, according to Polish Standards, i.e., characteristics of sewage sludge, determination of dry residue and water content (PN-EN 12880:2004) [36] and characteristics of sewage sludge, determination of loss on ignition of dry matter (PN-EN 12879:2004) [37].

\subsubsection{Determination of Total Heavy Metal Concentrations}

Determination of the total heavy metal concentrations $(\mathrm{Cd}, \mathrm{Cr}, \mathrm{Cu}, \mathrm{Hg}, \mathrm{Ni}, \mathrm{Pb}$, and $\mathrm{Zn}$ ) included sludge sample preparation, i.e., initial drying for $48 \mathrm{~h}$ at room temperature until air-dried and then to constant mass at $105{ }^{\circ} \mathrm{C}$. In the next step, sludge samples were milled in a mortar grinder. Afterwards, $0.2 \mathrm{~g}$ of sample was digested with nitric acid $\left(\mathrm{HNO}_{3}\right)$ and hydrochloric acid $(\mathrm{HCl})$ in a Teflon flask, using a microwave digestion system (Multiwave 3000, Anton Paar GmbH, Graz, Austria). Obtained solutions were filtered through fine filters $(0.45 \mu \mathrm{m})$ and diluted with $5 \% \mathrm{HNO}_{3}$ to a volume of $50 \mathrm{~mL}$. Samples were stored at $4{ }^{\circ} \mathrm{C}$ prior to analysis. The total heavy metal concentrations were determined using inductively coupled plasma optical spectrometry (Avio 200 ICP-OES, PerkinElmer Inc., Waltham, MA, USA). Mercury was assayed with cold vapor atomic absorption spectrometry (CVAAS). All standards were prepared on the day of analysis. The limits of detection (LODs) were $0.4,0.4,0.4,0.1$, 
$0.8,0.8$, and $4.2 \mathrm{mg} \mathrm{kg}^{-1}$ for $\mathrm{Cd}, \mathrm{Cr}, \mathrm{Cu}, \mathrm{Hg}, \mathrm{Ni}, \mathrm{Pb}$, and $\mathrm{Zn}$, respectively. The measurements were performed in triplicate.

\subsubsection{Sequential Extraction of Heavy Metals in Sewage Sludge}

To determine the chemical forms of heavy metals in sludge samples, the three-step chemical sequential extraction procedure of the Community Bureau of Reference (BCR; now the Standards, Measurements and Testing Programme), was used. Additionally, after completion of the sequential extraction procedure, the residual heavy metal contents were determined. The concentrations of heavy metals in water extracts were analyzed with inductively coupled plasma optical spectrometry (Avio 200 ICP-OES, PerkinElmer Inc., Waltham, MA, USA). The experiments were performed in triplicate. A scheme of the sequential extraction is shown in Table 2.

Table 2. Scheme of the Community Bureau of Reference (BCR) sequential extraction procedure $[8,19,20]$.

\begin{tabular}{|c|c|c|}
\hline & Fraction & BCR Procedure \\
\hline $\mathrm{F} 1$ & $\begin{array}{l}\text { Acid soluble/exchangeable } \\
\text { fraction; bound to carbonates } \\
\text { (mobile) }\end{array}$ & $\begin{array}{l}\text { Add } 20 \mathrm{~mL} \text { of } 0.11 \mathrm{~mol} \cdot \mathrm{L}^{-1} \text { acetic acid }\left(\mathrm{CH}_{3} \mathrm{COOH}\right) \text { to } 0.5 \mathrm{~g} \text { of } \\
\text { sludge sample. Shake for } 16-\mathrm{h} \text {. }\end{array}$ \\
\hline $\mathrm{F} 2$ & $\begin{array}{l}\text { Reducible fraction; bound to Mn } \\
\text { and Fe oxides (mobile) }\end{array}$ & $\begin{array}{l}\text { Add } 20 \mathrm{~mL} 0.1 \mathrm{~mol} \cdot \mathrm{L}^{-1} \text { hydroxylamine hydrochloride } \\
\left(\mathrm{NH}_{2} \mathrm{OH} \cdot \mathrm{HCl} \text {; adjusted with } \mathrm{HNO}_{3} \text { to } \mathrm{pH}=2\right) \text { to residue } \\
\text { from first step of extraction. Shake for } 16 \mathrm{~h} \text {. }\end{array}$ \\
\hline F3 & $\begin{array}{l}\text { Oxidizable fraction; bound to } \\
\text { organic matter and sulfides } \\
\text { (immobile) }\end{array}$ & $\begin{array}{l}\text { Add } 5 \mathrm{~mL} \text { of } 8.8 \mathrm{~mol} \cdot \mathrm{L}^{-1} \text { hydrogen peroxide }\left(\mathrm{H}_{2} \mathrm{O}_{2}\right) \text { and } \\
\text { incubate at } 85^{\circ} \mathrm{C} \text { for } 1 \mathrm{~h} \text { (repeat the procedure twice). } \\
\text { Afterwards, add } 25 \mathrm{~mL} \text { of } 1 \mathrm{~mol} \mathrm{~L}-1 \text { ammonium acetate } \\
\left(\mathrm{CH}_{3} \mathrm{COONH} \mathrm{H}_{4} \text {; adjusted with } \mathrm{HNO}_{3} \text { to } \mathrm{pH}=2\right) \text { to residue } \\
\text { from second step of extraction. Shake for } 16 \mathrm{~h} \text {. }\end{array}$ \\
\hline $\mathrm{F} 4$ & Residual fraction (immobile) & $\begin{array}{l}\text { Add } 5 \mathrm{~mL} \mathrm{HNO}_{3} \text { and } 15 \mathrm{~mL} \mathrm{HCl} \text { to residue from third step of } \\
\text { extraction. }\end{array}$ \\
\hline
\end{tabular}

\subsection{Pollution Level and Ecological Risk}

To assess the pollution level and potential ecological risk of heavy metals in sewage sludge, the following indices were used: Geoaccumulation Index $\left(\mathrm{I}_{\mathrm{geo}}\right)$ [24], Potential Ecological Risk Factor (ER) [25], Individual Contamination Factor (ICF) [23,26], Risk Assessment Code (RAC) [27] and Ecological Risk Factor (ERF) - the author's index. The Igeo and ER indices refer to total concentrations of heavy metals, while ICF, RAC, and ERF refer to their chemical forms. The pollution levels and ecological risks of heavy metals in sewage sludge were calculated by the equations shown in Table 3 .

\subsection{Statistical Analysis}

All calculations were performed using Statistica 12.0 (StatSoft) and Excel 2013 (Microsoft Office Standard). The occurrence of a linear correlation between analyzed variables was evaluated by Pearson's correlation coefficient (r). Data analysis also included means $(\bar{x})$ and standard deviations (SD). 
Table 3. The pollution level and ecological risk criteria for heavy metals.

\begin{tabular}{|c|c|c|c|}
\hline Indices & Equation with Description & Category & Description and Abbreviations \\
\hline Geoaccumulation Index (Igeo $)$ [24] & $\begin{array}{c}I_{g e o}=\log _{2}\left(\frac{C_{n}}{1.5 B_{n}}\right) \\
\mathrm{C}_{\mathrm{n}}-\text { measured concentration of metal in } \\
\text { the sludge sample; } \\
\mathrm{B}_{\mathrm{n}}-\text { geochemical background value in } \\
\text { the Earth's crust [38] }\end{array}$ & $\begin{array}{l}\mathrm{I}_{\text {geo }} \leq 0 \\
0<\mathrm{I}_{\text {geo }} \leq 1 \\
1<\mathrm{I}_{\text {geo }} \leq 2 \\
2<\mathrm{I}_{\text {geo }} \leq 3 \\
3<\mathrm{I}_{\text {geo }} \leq 4 \\
4<\mathrm{I}_{\text {geo }} \leq 5 \\
\quad 5<\mathrm{I}_{\text {geo }}\end{array}$ & $\begin{array}{c}\text { Practically uncontaminated (PUC) } \\
\text { Uncontaminated to moderately contaminated (U-MC) } \\
\text { Moderately contaminated (MC) } \\
\text { Moderately to Heavily contaminated (M-HC) } \\
\text { Heavily contaminated (HC) } \\
\text { Heavily to Extremely contaminated (H-EC) } \\
\text { Extremely contaminated (EC) }\end{array}$ \\
\hline Potential Ecological Risk Factor (ER) [25] & $\begin{array}{l}\qquad E R=T_{f}^{i} C_{f} \\
\mathrm{~T}_{\mathrm{f}}^{\mathrm{i}} \text {-the toxic response factor of metal; } \\
\mathrm{C}_{\mathrm{f}} \text { - single metal pollution factor }\end{array}$ & $\begin{array}{c}\mathrm{ER} \leq 40 \\
40<\mathrm{ER} \leq 80 \\
80<\mathrm{ER} \leq 160 \\
160<\mathrm{ER} \leq 320 \\
\mathrm{ER}>320\end{array}$ & $\begin{array}{c}\text { Low risk (LR) } \\
\text { Moderate risk (MR) } \\
\text { Considerable risk (CR) } \\
\text { High risk (HR) } \\
\text { Very high risk (VHR) }\end{array}$ \\
\hline Individual Contamination Factor (ICF) $[23,26]$ & $\begin{array}{c}I C F=\frac{F_{1}+F_{2}+F_{3}}{F_{4}} \\
\mathrm{~F}_{1}, \mathrm{~F}_{2}, \mathrm{~F}_{3}, \mathrm{~F}_{4} \text {-the content of metal in } \\
\text { exchangeable/carbonate, oxidizable, } \\
\text { reducible and residual fraction }\end{array}$ & $\begin{array}{c}\mathrm{CF} \leq 1 \\
1<\mathrm{CF} \leq 3 \\
3<\mathrm{CF} \leq 6 \\
\mathrm{CF}>6\end{array}$ & $\begin{array}{c}\text { Low contamination (LC) } \\
\text { Moderate contamination (MC) } \\
\text { Considerable contamination (CC) } \\
\text { Very high contamination (VHC) }\end{array}$ \\
\hline Risk Assessment Code (RAC) [27] & $\begin{array}{c}R A C=F_{1}+F_{2} \\
\mathrm{~F}_{1}, \mathrm{~F}_{2} \text { - the percentage share of metal in } \\
\text { exchangeable/carbonate and reducible } \\
\text { fractions }\end{array}$ & $\begin{array}{c}\text { RAC } \leq 1 \% \\
1 \%<\text { RAC } \leq 10 \% \\
10 \%<\text { RAC } \leq 30 \% \\
30 \%<\text { RAC } \leq 50 \% \\
50 \%<\text { RAC }\end{array}$ & $\begin{array}{c}\text { No risk (NR) } \\
\text { Low risk (LR) } \\
\text { Medium risk (MR) } \\
\text { High risk (HR) } \\
\text { Very high risk (VHR) }\end{array}$ \\
\hline $\begin{array}{c}\text { Ecological Risk Factor (ERF)_author's index } \\
\text { [This study] }\end{array}$ & $\begin{array}{c}E R F=\frac{F_{1}+F_{2}}{F_{3}+F_{4}} \\
\mathrm{~F}_{1}, \mathrm{~F}_{2}, \mathrm{~F}_{3}, \mathrm{~F}_{4} \text { - the content of metal in } \\
\text { exchangeable /carbonate, reducible, } \\
\text { oxidizable and residual fractions }\end{array}$ & $\begin{array}{c}0<\mathrm{ERF} \leq 0.4 \\
0.4<\mathrm{ERF} \leq 1 \\
1<\mathrm{ERF}\end{array}$ & $\begin{array}{l}\text { Low risk (LR) } \\
\text { Medium risk (MR) } \\
\text { High risk (HR) }\end{array}$ \\
\hline
\end{tabular}




\section{Results and Discussion}

\subsection{Physicochemical Characteristics of Sewage Sludge}

The physicochemical characteristics of sewage sludge are shown in Table 4 . The pH of sludge samples ranged from 5.4 to 7.4. The lowest $\mathrm{pH}$ levels were found in the thickened primary sludge (S2) and mixed sludge (S5). Moreover, the redox potential was in the range of -350.0 to $-175.0 \mathrm{mV}$. The lowest Eh was found for thickened primary sludge (S2), while the highest was found for primary sludge (S1). Furthermore, the sludge samples at particular sampling points differed in their dry matter content. It is likely that this was related to the type of treatment that was applied to the sludge processing. The dry matter content ranged from $0.6 \%$ to $20.3 \%$ for primary and dehydrated sludge, respectively, which also reflected the level of sludge hydration, i.e., $99.4 \%$ and $79.7 \%$, respectively. The highest organic matter content was found in the primary sludge $(83.3 \% \mathrm{DM})$, while the lowest was found for sludge after anaerobic digestion $(61.8 \% \mathrm{DM})$. The above results are consistent with those presented in other studies [8,39].

Table 4. Physicochemical characteristics of sewage sludge.

\begin{tabular}{cccccc}
\hline \multirow{2}{*}{ Sampling Points } & $\mathbf{p H}$ & $\mathbf{E h}$ & $\mathbf{D M}$ & $\mathbf{O M}$ & Moisture \\
\cline { 3 - 6 } & & $\mathbf{m V}$ & $\mathbf{\%}$ & $\mathbf{\%} \mathbf{D M}$ & $\mathbf{\%}$ \\
\hline S1 & 7.4 & -175 & 0.6 & 83.3 & 99.4 \\
S2 & 5.4 & -350 & 6.5 & 78.5 & 97.5 \\
S3 & 7.4 & -188 & 0.9 & 77.8 & 99.1 \\
S4 & 7.1 & -177 & 7.1 & 70.4 & 92.8 \\
S5 & 5.7 & -273 & 5.4 & 75.9 & 94.6 \\
S6 & 6.7 & -343 & 3.4 & 61.8 & 96.6 \\
S7 & 7.4 & -272 & 20.3 & 64.0 & 79.7 \\
\hline
\end{tabular}

\subsection{Total Heavy Metal Concentrations}

The total heavy metal concentrations in sludge samples are shown in Table 5. The experiment conducted showed that the mean concentrations of heavy metals in sewage sludge at different stages of processing, were in the following order: $\mathrm{Zn}>\mathrm{Cu}>\mathrm{Pb}>\mathrm{Cr}>\mathrm{Ni}>\mathrm{Cd}>\mathrm{Hg}$ (S1); $\mathrm{Zn}>\mathrm{Cu}>\mathrm{Pb}$ $>\mathrm{Ni}>\mathrm{Cr}>\mathrm{Cd}>\mathrm{Hg}(\mathrm{S} 2, \mathrm{~S} 3, \mathrm{~S} 7) ; \mathrm{Zn}>\mathrm{Pb}>\mathrm{Cu}>\mathrm{Ni}>\mathrm{Cr}>\mathrm{Cd}>\mathrm{Hg}(\mathrm{S} 5, \mathrm{~S} 6)$. Slight fluctuations were observed with regard to the order of individual metals $(\mathrm{Cu}-\mathrm{Pb}, \mathrm{Cr}-\mathrm{Ni})$. However, $\mathrm{Zn}$ and $\mathrm{Cu}$ were found to be the most dominant heavy metals in sewage sludge at different stages of processing, while $\mathrm{Cd}$ and $\mathrm{Hg}$ were the least noticeable. The above observations are in good agreement with the results obtained by other researchers [2,20,40]. Moreover, it should be emphasized that according to the literature, $\mathrm{Cd}$ and $\mathrm{Hg}$ (in excess concentrations) are highly toxic, mainly to humans and animals (and are less toxic to plants), while $\mathrm{Zn}$ and $\mathrm{Cu}$ inversely [41]. This is even more important when taking into account that the main method of sludge management is its agricultural use. However, in this study the total concentrations of heavy metals did not exceed the permissible standards for sewage sludge in Poland (J. L. 2010, No. 137, item. 924) [15] and EU (86/278/EEC) [16].

The lowest content of heavy metals was found in the thickened primary sludge and mixed sludge, i.e., $1382.1 \mathrm{mg} \cdot \mathrm{kg}^{-1}$ and $1764.4 \mathrm{mg} \cdot \mathrm{kg}^{-1}$, respectively, whereas the highest was found in sewage sludge after anaerobic digestion and dehydration, i.e., $2400.8 \mathrm{mg} \cdot \mathrm{kg}^{-1}$ and $2396.7 \mathrm{mg} \cdot \mathrm{kg}^{-1}$, respectively. According to Álvarez et al. (2002) [20], this was probably related to the weight loss of the fresh sludge during the anaerobic digestion process, and at the later stage to an increase of dry matter content during sludge dehydration. The impact of an increase in DM content on the total heavy metal concentrations in sludge was also observed in the case of dewatered sludge, which was characterized with higher DM and metal contents compared to primary or secondary sludge. The only exception was primary and secondary sludge after thickening, in which, despite the increase in dry matter content, the total metal content decreased compared to the non-thickened sludge, which in turn affected the characteristics of the mixed sludge. It can be assumed that as a result of the thickening processes, the heavy metals in 
the sewage sludge have probably passed into the liquid phase. Another reason for this phenomenon may also be poor mixing of the sludge and the conditioning agent (in the case of secondary sludge). In addition, it was also observed that in the sludge after anaerobic digestion, despite the decrease in dry matter content, the total heavy metal concentrations were maintained at high levels. This could be related to the good binding of these elements to the solid particles of sludge or to the changes in its characteristics during the anaerobic digestion. The above results partly confirm the author's previous observations $[8,42]$.

Table 5. Total concentrations of heavy metals in sewage sludge.

\begin{tabular}{|c|c|c|c|c|c|c|c|}
\hline Metal & S1 & $\mathrm{S} 2$ & S3 & $\mathrm{S} 4$ & S5 & S6 & S7 \\
\hline $\mathrm{Cd}$ & $2.7 \pm 0.1$ & $1.8 \pm 0.2$ & $3.0 \pm 0.2$ & $3.1 \pm 0.4$ & $2.3 \pm 0.1$ & $4.0 \pm 0.2$ & $4.1 \pm 0.8$ \\
\hline $\mathrm{Cu}$ & $123.6 \pm 13.1$ & $104.1 \pm 20.2$ & $138.3 \pm 11.4$ & $143.0 \pm 26.2$ & $117.7 \pm 2.4$ & $188.9 \pm 12.5$ & $194.0 \pm 45.0$ \\
\hline $\mathrm{Ni}$ & $55.0 \pm 21.1$ & $51.2 \pm 18.8$ & $62.0 \pm 14.8$ & $64.1 \pm 22.0$ & $58.7 \pm 22.7$ & $98.1 \pm 21.0$ & $95.2 \pm 20.2$ \\
\hline $\mathrm{Hg}$ & $1.0 \pm 2.8$ & $0.3 \pm 1.3$ & $0.7 \pm 1.6$ & $0.5 \pm 4.0$ & $1.0 \pm 3.5$ & $1.1 \pm 3.7$ & $1.0 \pm 1.3$ \\
\hline Sum & 1792.6 & 1382.1 & 2037.5 & 1972.5 & 1764.6 & 2396.7 & 2400.8 \\
\hline
\end{tabular}

Results are expressed as the mean \pm standard deviation in $\mathrm{mg} \mathrm{kg}^{-1}$ of dry matter.

Table 6 presents the results of the Pearson's correlation analysis for heavy metals in sewage sludge. The obtained results indicate the presence of strong positive correlations between the selected elements, with the exception of $\mathrm{Hg}$. Similar observations have also been made by other researchers [3,21,40]. It can be assumed that statistically significant correlations among the heavy metals may prove that they possibly have a similar accumulation behavior or originate from the same sources of pollution. However, in this case, further studies and analysis should be conducted.

Table 6. Pearson's correlation coefficients between heavy metals in sewage sludge.

\begin{tabular}{cccccccc}
\hline & $\mathbf{C d}$ & $\mathbf{C r}$ & $\mathbf{C u}$ & $\mathbf{N i}$ & $\mathbf{P b}$ & $\mathbf{Z n}$ & $\mathbf{H g}$ \\
\hline $\mathrm{Cd}$ & 1.0000 & & & & & & \\
$\mathrm{Cr}$ & $\mathbf{0 . 9 0 9 8}$ & 1.0000 & & & & & \\
$\mathrm{Cu}$ & $\mathbf{0 . 9 8 2 3}$ & $\mathbf{0 . 8 4 3 0}$ & 1.0000 & & & & \\
$\mathrm{Ni}$ & $\mathbf{0 . 9 2 8 7}$ & $\mathbf{0 . 7 7 0 3}$ & $\mathbf{0 . 9 7 8 0}$ & 1.0000 & & & \\
$\mathrm{~Pb}$ & $\mathbf{0 . 9 8 2 5}$ & $\mathbf{0 . 8 8 1 1}$ & $\mathbf{0 . 9 9 2 5}$ & $\mathbf{0 . 9 7 5 2}$ & 1.0000 & & \\
$\mathrm{Zn}$ & $\mathbf{0 . 9 7 1 6}$ & $\mathbf{0 . 9 2 4 5}$ & $\mathbf{0 . 9 3 5 9}$ & $\mathbf{0 . 8 7 6 7}$ & $\mathbf{0 . 9 5 7 9}$ & 1.0000 & \\
$\mathrm{Hg}$ & 0.5109 & 0.6440 & 0.4734 & 0.4937 & 0.5534 & 0.5940 & 1.0000 \\
\hline \multicolumn{7}{c}{ Bold-significant correlations at $p<0.05}$. & \\
\end{tabular}

\subsection{Chemical Speciation of Heavy Metals}

The results of BCR sequential extraction of heavy metals in the sludge samples are shown in Table 7, whereas the distribution of heavy metals is presented in Figure 3. The sequential extraction analysis did not cover $\mathrm{Hg}$, due to its very low concentration in the sludge samples. Moreover, in some cases the concentrations of $\mathrm{Cd}, \mathrm{Cr}$ and $\mathrm{Pb}$ bound to different chemical forms, were below their limits of detection (LODs).

Verification of the BCR sequential extraction procedure was performed by comparing the sum of the four fractions with the total concentrations of heavy metals in sludge samples, i.e., using recovery rate $(\mathrm{R})$. The recovery rate of heavy metals ranged from $41.1 \%$ to $124.4 \%$ (Table 7 ). The obtained results confirmed that the BCR sequential extraction procedure is adequate and reliable for detecting the speciation of analyzed heavy metals. Similar results were obtained by other researchers, for example, 64.5-106.0\% [43], 29.7-117.9\% [8], and 81.2-130.9\% [21]. The research conducted revealed that $\mathrm{Zn}$ and $\mathrm{Cu}$ occurred in the largest quantities, i.e., $14.3-600.5 \mathrm{mg} \cdot \mathrm{kg}^{-1}$ and $0.5-210.5 \mathrm{mg} \cdot \mathrm{kg}^{-1}$, respectively, while Cd occurred in the smallest quantities, i.e., $0.7-2.2 \mathrm{mg} \cdot \mathrm{kg}^{-1}$ (Table 7 ). 
The distribution of individual heavy metals in the selected fractions of sewage sludge varied at particular sampling points: Cd-F3 > F4 > F2 > F1 (S1), F2, F3 > F1, F4 (S2), F2,F3 > F4 > F1 (S3,S5), F4 > F3 > F2 > F1 (S4), F3 > F4 > F2 > F1 (S6,S7); Cr - F3 > F4 > F1, F2 (S1,S2,S3,S4,S6), F3 > F4 > F1 > F2 (S5,S7); Cu-F3 > F4 > F2 > F1 (S1-S7); Ni - F4 > F3 > F1 > F2 (S1,S3,S4), F4 > F1 > F3 > F2 (S2,S5,S6,S7); Pb-F4 > F3 > F1,F2 (S1), S4 > F3 > F2 > F1 (S2); F4 > F3 > F1 > F2 (S4), F4 > F3 > F1,F2 $(\mathrm{S} 3, \mathrm{~S} 5, \mathrm{~S} 6, \mathrm{~S} 7)$ and $\mathrm{Zn}-\mathrm{F} 2>\mathrm{F} 3>\mathrm{F} 1>\mathrm{F} 4(\mathrm{~S} 1, \mathrm{~S} 3, \mathrm{~S} 4, \mathrm{~S} 5, \mathrm{~S} 6), \mathrm{F} 2>\mathrm{F} 1>\mathrm{F} 3>\mathrm{F} 4(\mathrm{~S} 2, \mathrm{~S} 7)$. In summary, sludge at different stages of its processing exhibited higher concentrations of heavy metals bound to the immobile fractions (F3 and F4), compared to the mobile ones (F1 and F2). The observations presented above were confirmed by other researchers $[8,17,20]$. The exception was zinc, in which case the percentage share in the mobile fractions prevailed over the mobile ones and ranged from $55.0 \%$ (S7) to $70.4 \%$ (S2). Also noteworthy are cadmium and nickel, for which the share in the mobile fractions ranged from $23.4 \%$ (S7) to $51.0 \%$ (S2), and from $27.1 \%$ (S4) to $40.8 \%$ (S5), respectively. Similar results were presented by Yang et al. (2017) [17] who indicated that the percentage share of $\mathrm{Zn}, \mathrm{Cd}$, and $\mathrm{Ni}$ in the mobile fractions of sewage sludge ranged between $59.57 \%$ and $79.12 \%, 48.90 \%$ and $60.52 \%$, and between $34.67 \%$ and $70.34 \%$, respectively. Also, other scientists confirmed that zinc showed the greatest bioavailability among the heavy metals considered $[20,21,40]$. The obtained results also revealed that chromium, copper, and lead were predominantly present in the immobile fractions, with percentage shares in the ranges 97.6 (S7)-99.5\% (S2); 92.7 (S2)-99.4\% (S6) and 97.3 (S2)-98.8\% (S4), respectively (Figure 3). Generally, in this study, the distribution of heavy metals bound to the mobile fractions decreased gradually over successive stages of sewage sludge processing. The above-mentioned observations were also confirmed by other researchers [20,44]. This is a positive effect, when taking into account the possibility of secondary pollution of water and soils with heavy metals and, as a consequence, their bioaccumulation in living organisms, especially in the case of agricultural use of sludge. Moreover, it must be stressed that processes used at WWTPs may significantly influence the sewage sludge characteristics, e.g., its $\mathrm{pH}$ value, the content of total and organic matter, etc. [8]. However, so far, there are not many publications on the heavy metal content and their chemical forms in sewage sludge, during the various stages of processing. Mostly these works are devoted to one selected type of sludge. For example, it was found that thickening of secondary sludge decreases the content of heavy metals in mobile fractions, compared to their content in the primary and secondary sludge [44]. The above findings are in good agreement with the results obtained in this study, as well as with the previous one [8]. Furthermore, the obtained results showed an increase in the content of heavy metals in mobile forms in the mixed sludge. This was probably caused by the decrease in $\mathrm{pH}$ and Eh values, compared to the sludge characteristics in the previous processing stages. Moreover, it was also found that anaerobic digestion and dehydration of sewage sludge reduced the mobility of heavy metals, which can minimize the level of potential risk posed by these elements. The probable reason was the increase of $\mathrm{pH}$, during the processes that were conducted. Generally, according to the literature, the main factors affecting heavy metal availability from sludge are $\mathrm{pH}$ and Eh [45].

Table 8 presents the statistical summary data for $\mathrm{pH}$, Eh, DM, and OM, as well as for heavy metals in the sewage sludge. The concentrations of metals below the limits of detection were set to zero. The obtained results indicate the presence of strong correlations between the content of $\mathrm{Zn}, \mathrm{Ni}$ and $\mathrm{Cu}$ bound to the mobile/immobile fractions, and $\mathrm{pH}$ value; i.e., F2 (0.79) and F3 (0.88) for $\mathrm{Zn}$ and $\mathrm{Ni}$, respectively, and F1 (-0.81), F4 (0.78) for $\mathrm{Cu}$. Moreover, negative correlations were found between the concentration of $\mathrm{Zn}(\mathrm{F} 1)$ and Eh value (-0.92). The obtained results also indicate the presence of positive correlations between the content of $\mathrm{Cr}(\mathrm{F} 1)$ and $\mathrm{DM}(0.85)$, and $\mathrm{Cr}(\mathrm{F} 1)$ and $\mathrm{OM}$ (0.84). However, in this case, further analysis should be conducted (including seasonal changes in the physicochemical characteristic of sewage sludge). Moreover, there is some literature which confirms the existence of significant correlations between the selected physicochemical properties of sewage sludge and concentrations of easily mobile and available heavy metal fractions. For example, Wang et al. (2006) [44] found that $\mathrm{Cu}, \mathrm{Cr}$, and $\mathrm{Pb}$ in mobile fractions (F1+F2) were negatively correlated with the $\mathrm{pH}$ value of sludge collected at different stages of processing (primary sludge, active sludge, 
thickened sludge, digested sludge and dewatered sludge). In turn, other scientists indicated that in dewatered sludge from five different WWTPs, Ni and Pb (F2) were positively correlated with $\mathrm{pH}$ values. Moreover, they also found that $\mathrm{Pb}$ in mobile fractions (F1 and F2) was positively correlated with OM content, while and Zn (F1 and F2) negatively [21].

Table 7. Heavy metal concentrations in individual fractions of sewage sludge.

\begin{tabular}{|c|c|c|c|c|c|c|c|c|}
\hline Metal & Fraction & S1 & $\mathrm{S} 2$ & S3 & $\mathrm{S} 4$ & S5 & S6 & S7 \\
\hline \multicolumn{9}{|c|}{$\mathrm{mg} \cdot \mathrm{kg}^{-1} \mathrm{DM}$} \\
\hline \multirow{5}{*}{$\mathrm{Cd}$} & $\mathrm{F} 1$ & BDL & BDL & BDL & BDL & BDL & BDL & BDL \\
\hline & $\mathrm{F} 2$ & $0.9 \pm 0.0$ & $1.1 \pm 0.0$ & $1.2 \pm 0.1$ & $0.9 \pm 0.1$ & $1.1 \pm 0.0$ & $1.3 \pm 0.0$ & $1.1 \pm 0.1$ \\
\hline & F3 & $1.2 \pm 0.3$ & $1.1 \pm 0.2$ & $1.2 \pm 0.1$ & $1.3 \pm 0.1$ & $1.1 \pm 0.3$ & $1.9 \pm 0.1$ & $2.2 \pm 0.2$ \\
\hline & F4 & $0.8 \pm 0.1$ & BDL & $1.1 \pm 0.4$ & $1.4 \pm 0.2$ & $0.7 \pm 0.0$ & $1.8 \pm 0.0$ & $1.5 \pm 0.1$ \\
\hline & $\mathrm{R}, \%$ & 106.8 & 124.4 & 112.2 & 114.1 & 126.7 & 123.6 & 119.2 \\
\hline \multirow{5}{*}{$\mathrm{Cr}$} & $\mathrm{F} 1$ & BDL & BDL & BDL & BDL & $0.6 \pm 0.0$ & BDL & $1.2 \pm 0.0$ \\
\hline & $\mathrm{F} 2$ & BDL & BDL & BDL & BDL & BDL & BDL & BDL \\
\hline & F3 & $19.7 \pm 8.2$ & $17.0 \pm 4.5$ & $23.5 \pm 1.4$ & $22.1 \pm 0.4$ & $17.7 \pm 1.6$ & $25.2 \pm 0.5$ & $25.5 \pm 0.7$ \\
\hline & F4 & $16.0 \pm 0.6$ & $8.0 \pm 0.8$ & $15.3 \pm 1.3$ & $19.0 \pm 2.6$ & $12.6 \pm 0.5$ & $24.8 \pm 0.7$ & $22.2 \pm 0.2$ \\
\hline & $\mathrm{R}, \%$ & 62.3 & 71.6 & 70.9 & 65.5 & 58.0 & 73.3 & 73.0 \\
\hline \multirow{5}{*}{$\mathrm{Cu}$} & $\mathrm{F} 1$ & $0.7 \pm 0.1$ & $2.3 \pm 0.1$ & $0.8 \pm 0.1$ & $0.9 \pm 0.0$ & $1.9 \pm 0.0$ & $0.5 \pm 0.1$ & $1.4 \pm 0.1$ \\
\hline & F2 & $4.8 \pm 1.2$ & $6.9 \pm 2.4$ & $1.6 \pm 0.2$ & $1.1 \pm 0.1$ & $3.5 \pm 05$ & $0.7 \pm 0.1$ & $1.7 \pm 0.1$ \\
\hline & F3 & $118.3 \pm 30.4$ & $110.8 \pm 23.1$ & $141.1 \pm 7.0$ & $151.7 \pm 5.6$ & $126.9 \pm 14.8$ & $210.5 \pm 3.8$ & $198.8 \pm 6.3$ \\
\hline & $\mathrm{F} 4$ & $13.4 \pm 2.1$ & $4.9 \pm 0.5$ & $11.1 \pm 1.6$ & $12.1 \pm 0.4$ & $7.6 \pm 0.5$ & $16.5 \pm 0.4$ & $14.5 \pm 0.5$ \\
\hline & $\mathrm{R} ; \%$ & 110.9 & 120.0 & 111.8 & 116.0 & 118.8 & 120.8 & 111.5 \\
\hline \multirow{5}{*}{$\mathrm{Ni}$} & $\mathrm{F} 1$ & $5.4 \pm 0.2$ & $5.4 \pm 0.2$ & $5.8 \pm 0.9$ & $5.6 \pm 0.2$ & $7.6 \pm 0.1$ & $9.4 \pm 0.0$ & $11.2 \pm 0.1$ \\
\hline & $\mathrm{F} 2$ & $3.6 \pm 0.1$ & $1.8 \pm 0.0$ & $3.7 \pm 0.2$ & $3.6 \pm 0.2$ & $2.6 \pm 0.1$ & $4.7 \pm 0.1$ & $2.9 \pm 0.0$ \\
\hline & F3 & $8.3 \pm 8.9$ & $4.2 \pm 2.8$ & $8.2 \pm 1.1$ & $9.5 \pm 0.1$ & $3.7 \pm 0.1$ & $7.3 \pm 0.3$ & $7.1 \pm 0.4$ \\
\hline & $\mathrm{F} 4$ & $13.9 \pm 1.1$ & $10.9 \pm 4.0$ & $13.2 \pm 2.3$ & $15.2 \pm 3.3$ & $11.1 \pm 0.4$ & $19.1 \pm 2.4$ & $18.0 \pm 0.8$ \\
\hline & $\mathrm{R} ; \%$ & 56.9 & 43.7 & 49.9 & 52.9 & 42.5 & 41.4 & 41.1 \\
\hline \multirow{5}{*}{$\mathbf{P b}$} & $\mathrm{F} 1$ & BDL & BDL & BDL & $1.1 \pm 0.7$ & BDL & BDL & BDL \\
\hline & $\mathrm{F} 2$ & BDL & $1.2 \pm 0.1$ & BDL & BDL & BDL & BDL & BDL \\
\hline & F3 & $18.0 \pm 14.8$ & $19.5 \pm 10.0$ & $7.9 \pm 1.0$ & $3.8 \pm 0.3$ & $10.2 \pm 0.6$ & $13.3 \pm 0.4$ & $19.4 \pm 1.0$ \\
\hline & $\mathrm{F} 4$ & $65.3 \pm 4.8$ & $24.3 \pm 2.0$ & $74.5 \pm 10.7$ & $80.3 \pm 14.2$ & $52.8 \pm 4.9$ & $107.9 \pm 1.1$ & $93.9 \pm 5.5$ \\
\hline & $\mathrm{R} ; \%$ & 67.4 & 46.1 & 59.5 & 60.4 & 50.9 & 64.1 & 60.3 \\
\hline \multirow{5}{*}{ Zn } & F1 & $123.0 \pm 6.6$ & $308.1 \pm 10.2$ & $137.4 \pm 17.0$ & $94.1 \pm 4.8$ & $220.9 \pm 3.5$ & $230.5 \pm 7.4$ & $252.5 \pm 4.9$ \\
\hline & F2 & $538.1 \pm 11.3$ & $334.2 \pm 10.8$ & $555.6 \pm 23.1$ & $568.9 \pm 20.6$ & $482.1 \pm 15.4$ & $600.5 \pm 6.7$ & $545.1 \pm 10.4$ \\
\hline & F3 & $304.7 \pm 187.2$ & $256.2 \pm 135.0$ & $377.3 \pm 28.8$ & $455.6 \pm 34.6$ & $285.5 \pm 30.9$ & $560.1 \pm 20.3$ & $571.3 \pm 44.2$ \\
\hline & F4 & $57.5 \pm 6.7$ & $14.3 \pm 2.5$ & $59.1 \pm 10.0$ & $70.0 \pm 12.2$ & $34.6 \pm 3.0$ & $96.5 \pm 1.9$ & $81.8 \pm 3.2$ \\
\hline & $\mathrm{R} ; \%$ & 71.6 & 83.6 & 68.8 & 76.3 & 72.7 & 80.5 & 78.3 \\
\hline
\end{tabular}

Results are expressed as the mean \pm standard deviation in $\mathrm{mg} \mathrm{kg}^{-1}$ of dry matter; $\mathrm{R}$ - heavy metal recovery rate calculated by comparing the sum of the four fractions with the total concentrations of heavy metals in the sludge samples; BDL-below detection limit.

$\square \mathrm{F} 1 \quad \mathrm{~F} 2 \square \mathrm{F} 3 \quad \mathrm{~F} 4$

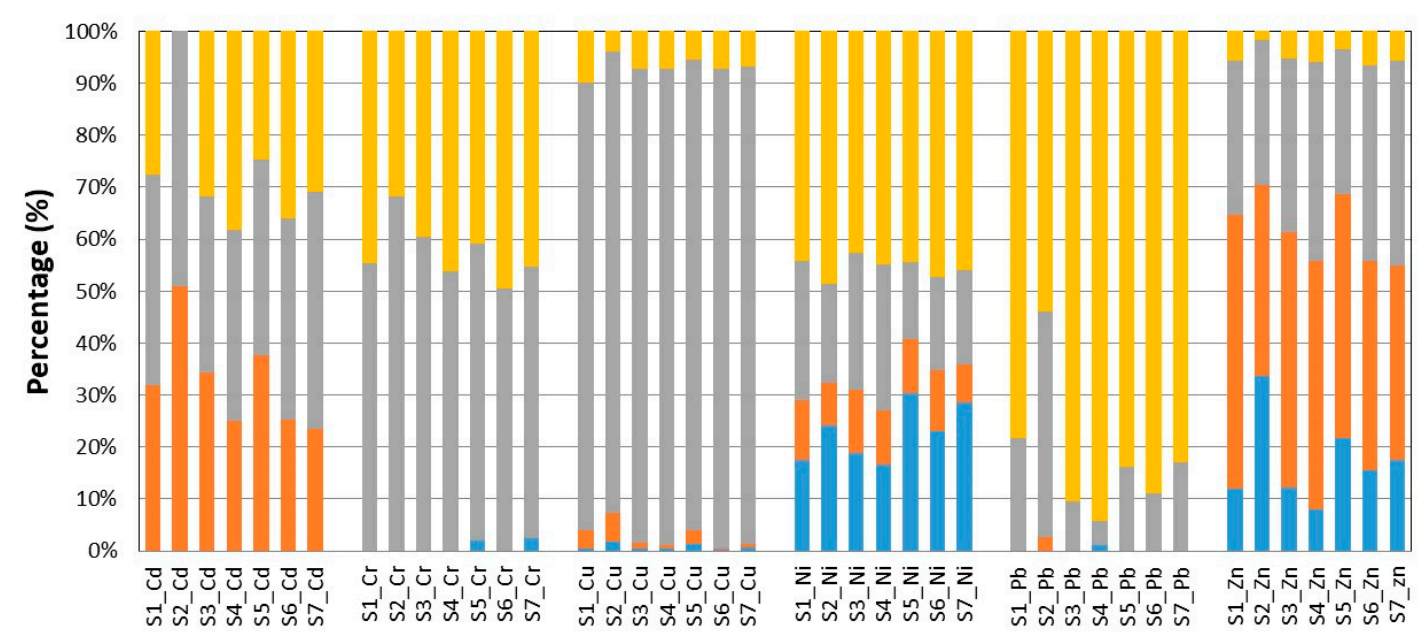

Heavy metals

Figure 3. Heavy metal distribution in sewage sludge. 
Table 8. Pearson's correlation coefficients between parameters of sewage sludge and concentrations of heavy metal fractions.

\begin{tabular}{|c|c|c|c|c|}
\hline $\mathrm{Cd}$ & F1 & F2 & F3 & F4 \\
\hline ph & $-*$ & -0.2487 & 0.3950 & 0.6567 \\
\hline Eh & $-*$ & -0.6903 & -0.3144 & 0.1519 \\
\hline $\mathrm{DM}$ & $-*$ & 0.0675 & 0.6888 & 0.2389 \\
\hline $\mathrm{OM}$ & $-*$ & 0.0493 & 0.6342 & 0.1709 \\
\hline $\mathrm{Cr}$ & F1 & F2 & F3 & F4 \\
\hline $\mathrm{pH}$ & 0.0624 & $-*$ & 0.7280 & 0.6414 \\
\hline Eh & -0.1557 & $-*$ & 0.0872 & 0.0460 \\
\hline $\mathrm{DM}$ & 0.8499 & $-*$ & 0.3444 & 0.3007 \\
\hline $\mathrm{OM}$ & 0.8356 & $-*$ & 0.2720 & 0.2303 \\
\hline $\mathrm{Cu}$ & F1 & F2 & F3 & F4 \\
\hline ph & -0.8119 & -0.5937 & 0.4028 & 0.7781 \\
\hline Eh & -0.4887 & -0.2252 & -0.2829 & 0.2106 \\
\hline $\mathrm{DM}$ & 0.3224 & -0.1630 & 0.4778 & 0.1323 \\
\hline $\mathrm{OM}$ & 0.3957 & -0.1056 & 0.4206 & 0.0513 \\
\hline $\mathrm{Ni}$ & F1 & F2 & F3 & F4 \\
\hline ph & 0.1668 & 0.6162 & 0.8836 & 0.5867 \\
\hline Eh & -0.4328 & 0.2535 & 0.6893 & -0.1007 \\
\hline $\mathrm{DM}$ & 0.7112 & -0.3795 & -0.1092 & 0.3833 \\
\hline $\mathrm{OM}$ & 0.6677 & -0.4475 & -0.1637 & 0.3164 \\
\hline $\mathrm{Pb}$ & F1 & F2 & F3 & F4 \\
\hline ph & 0.1932 & -0.6909 & -0.1555 & 0.6942 \\
\hline Eh & 0.4488 & -0.5595 & -0.4874 & 0.1307 \\
\hline DM & 0.0486 & 0.0129 & 0.3426 & 0.2183 \\
\hline OM & 0.0694 & 0.0776 & 0.3361 & 0.1439 \\
\hline $\mathrm{Zn}$ & F1 & F2 & F3 & F4 \\
\hline ph & -0.6627 & 0.7872 & 0.5452 & 0.7196 \\
\hline Eh & -0.9238 & 0.4600 & -0.1032 & 0.1377 \\
\hline $\mathrm{DM}$ & 0.4299 & -0.0416 & 0.5198 & 0.2137 \\
\hline $\mathrm{OM}$ & 0.4601 & -0.1153 & 0.4616 & 0.1389 \\
\hline
\end{tabular}

Bold—significant correlations at $p<0.05 ;{ }^{*}$ Concentration of heavy metal below the limit of detection at all sampling points (no statistical analysis).

Based on the above results, it can be stated that this work paid special attention to the necessity of analyzing changes in the physicochemical properties of sewage sludge and concentrations of heavy metals, especially with regard to their chemical forms, in the whole technological line of the WWTP. This approach can have a significant impact on the proper assessment of the potential ecological risk associated with the presence of these elements in sewage sludge.

\subsection{Assessment of Polluton Level and Ecological Risk}

The assessment of the pollution level and potential ecological risk of selected heavy metals in sewage sludge from the "Central" WWTP in Bytom, was carried out using two groups of indices. The obtained results are shown in Table 9.

The indices in the first group are focused on the total concentrations of heavy metals. The values of the Geoaccumulation Index ( $\mathrm{I}_{\text {geo }}$ ) revealed that sewage sludge, at different stages of processing was moderately to heavily contaminated with $\mathrm{Cd}, \mathrm{Cu}$, and $\mathrm{Hg}(2.1-3.3 ; 2.0-2.9$, and $1.5-3.5$, respectively), moderately contaminated with $\mathrm{Pb}$ (1.4-2.0), and heavily contaminated with $\mathrm{Zn}$ (3.4-4.2). According to $\mathrm{I}_{\text {geo, }}$, zinc posed the highest contamination in sewage sludge, while lead posed the lowest. In turn, the values of the Potential Ecological Risk Factor (ER), which additionally includes the toxicity of heavy metals, showed that level of ecological risk depended on sludge characteristics at different stages of processing. It indicated that mercury posed the highest potential risk (ER; 172.4-692.7) in 
sewage sludge (except S3). However, cadmium also posed a considerable to very high environmental risk (ER; 91.4-435.7). Moreover, the research also revealed that the activated sludge process (the most commonly applied biological process) carried out before introducing sludge to the secondary settling tank, as well as thickening (mechanical process assisted by the addition of a conditioning agent), had the greatest impact on the level of ecological risk associated with the presence of heavy metals in sewage sludge. Confirmation of the above fact is that heavy metals present in the secondary sludge posed the highest potential risk for the environment. The obtained results also revealed that mercury and cadmium are two of the major causes of sludge pollution, and at the same time may pose the highest potential ecological risk, despite their low content in the sewage sludge (at different stages of processing). In turn, zinc, which was the main pollutant in sewage sludge, did not pose a significant risk to the environment (except S3). Similar observations to those presented here were made by Li et al. (2015) [40] who found that dewatered sludge collected from three WWTPs (China) was moderately to heavily contaminated with $\mathrm{Cd}$ and $\mathrm{Hg}$ ( $\mathrm{I}_{\text {geo }} ; 2.87-3.64,2.14-2.75$, for $\mathrm{Cd}$ and $\mathrm{Hg}$, respectively), as well as moderately to very heavily contaminated by zinc ( $\left.\mathrm{I}_{\text {geo }} ; 2.41-3.07\right)$, where $\mathrm{Cd}$ and $\mathrm{Hg}$ posed a very high ecological risk (ER; 495.0-842.14 and 369.36-603.63 for $\mathrm{Cd}$ and $\mathrm{Hg}$, respectively), while zinc posed only moderate to considerable risk (ER; 11.94-18.92). The above results were partly confirmed by Yang et al. (2017) [17] who indicated that sewage sludge collected from four selected WWTPs (China) were extremely contaminated with $\mathrm{Cd}\left(\mathrm{I}_{\text {geo }} ; 6.53-7.18\right)$, which posed a very high environmental risk (ER; 4150.86-6521.55), despite its low content in sewage sludge. Also, Duan et al. (2017b) [11] confirmed that according to $I_{\text {geo }}$ and ER values, sludge was moderately to heavily contaminated with $\mathrm{Cd}\left(\mathrm{I}_{\text {geo }} ; 1.76-3.46\right)$ and posed a potential environmental threat (ER; 79.42-256.62). Whereas, in contrast to the above-mentioned results, other researchers who analyzed sewage sludge from five selected WWTPs (Poland) indicated that cadmium posed a low ecological risk [21]. This confirms that every type of sludge is different, and its characteristics depend on the processes used in WWTPs, as well as the nature of the treated wastewater [46]. Therefore, each type of sludge should be considered individually.

The second group of analyzed indices refers only to the chemical forms of heavy metals in sewage sludge. In accordance with the values of the Individual Contamination Factor (ICF), it was shown that regardless of the sampling point, sewage sludge was moderately to very highly polluted with $\mathrm{Zn}$ (ICF; 14.4-63.0), Cu (ICF; 9.2-24.7), Cd (ICF; 1.6-3.1), Cr (ICF; 1.2-2.1), and Ni (ICF; 1.1-1.3). It was also indicated that in accordance with Risk Assessment Code (RAC), the highest potential ecological risk may be posed by Zn (RAC; 55.0-70.4\%), Ni (RAC; $27.0-40.8 \%$ ), and Cd (RAC; $23.4-51.0 \%$ ). The above observations were partly confirmed by the Ecological Risk Factor (ERF)—author's index, whose values indicated that $\mathrm{Zn}, \mathrm{Ni}$, and $\mathrm{Cd}$ posed a potential environmental threat. Similar results were obtained by researchers who analyzed sewage sludge from several WWTPs, and found that $\mathrm{Zn}$ posed a high ecological risk, while $\mathrm{Cu}$ and $\mathrm{Cd}$ posed only medium threats [17]. In turn, other scientists found that heavy metals in selected sewage sludge posed low to very high ecological risks, i.e., $\mathrm{Zn}$ (high to very high), $\mathrm{Cu}$ (very high), Ni (high), Cd (medium) and Cr (low) [40].

In summary, according to the $\mathrm{I}_{\text {geo }}$ and ER values, heavy metals in dewatered sludge (S7) were ranked in the following order: $\mathrm{Zn}>\mathrm{Hg}>\mathrm{Cd}>\mathrm{Cu}>\mathrm{Pb}>\mathrm{Ni}>\mathrm{Cr}$ and $\mathrm{Hg}>\mathrm{Cd}>\mathrm{Cu}>\mathrm{Pb}>\mathrm{Zn}>\mathrm{Ni}$ $>\mathrm{Cr}$, respectively. In turn, according to ICF, RAC and ERF: $\mathrm{Zn}>\mathrm{Cu}>\mathrm{Cd}>\mathrm{Cr}, \mathrm{Ni}>\mathrm{Pb} ; \mathrm{Zn}>\mathrm{Ni}>\mathrm{Cd}$ $>\mathrm{Cr}>\mathrm{Cu}>\mathrm{Pb}$ and $\mathrm{Zn}>\mathrm{Ni}>\mathrm{Cd}>\mathrm{Cr}, \mathrm{Cu}, \mathrm{Pb}$, respectively. Moreover, the research conducted also revealed that processes used in the WWTP analyzed enabled the agricultural or natural use of sewage sludge, but they did not eliminate the ecological risk associated with the presence of heavy metals. Therefore, taking into account that these toxic elements may still accumulate in plants and cause health problems to humans and animals, or undergo leaching from soils to ground water, it is necessary to introduce methods which allow their content in wastewater to be reduced, and as a consequence also their content in sewage sludge. Among these methods, we can distinguish the natural process of biofiltration performed by invasive bivalves. This process is environmentally friendly and consumes less energy than precipitation, ion exchange, or membrane separation. Moreover, bivalves are aquatic 
organisms, which are characterized by relative tolerance to toxic substances, and have high biofiltration, as well as bioaccumulation features. They can be used for water disinfection, wastewater treatment, etc. After the process has been completed, the contaminated mollusks may be incinerated or stored in special landfills [47]. There are some studies focused on the bioaccumulation of heavy metals by bivalves from different environmental samples. For example, Rosa et al. (2014) [48] used C. fluminea for the removal of metals $(\mathrm{Al}, \mathrm{Cd}, \mathrm{Co}, \mathrm{Cu}, \mathrm{Fe}, \mathrm{Mn}, \mathrm{Ni}, \mathrm{Pb}$, and $\mathrm{Zn}$ ) from acid mine drainage. The experiment conducted showed that most of the metals removed from the water column were detected in the bivalves' shells. Other researchers examined the ability of $D$. polymorpha for removing selected metals $(\mathrm{Al}, \mathrm{Cr}, \mathrm{Cu}, \mathrm{Fe}, \mathrm{Mn}, \mathrm{Ni}$, and $\mathrm{Pb}$ ) from municipal effluent. The obtained results revealed that the highest percentage removed was obtained for $\mathrm{Cr}$, while the lowest was obtained for $\mathrm{Ni}$ (Magni et al., 2015) [49]. It must be emphasized that the above described method was applied for the removal of toxic elements from treated wastewater. However, the results presented here encourage conducting further research related to the possibility of using bivalves as a natural biofilter for removing metals from untreated (raw) wastewater. This approach can contribute to reducing the total content of heavy metals in the sewage sludge. Moreover, this also may constitute the next step toward minimizing the level of ecological risk associated with the presence of heavy metals in sewage sludge.

Table 9. Results of heavy metal pollution level and potential ecological risk in sewage sludge (bold indicates the highest levels).

\begin{tabular}{|c|c|c|c|c|c|c|c|c|}
\hline & Index & $\mathrm{Cd}$ & $\mathrm{Cr}$ & $\mathrm{Cu}$ & $\mathrm{Ni}$ & $\mathbf{P b}$ & $\mathrm{Zn}$ & $\mathrm{Hg}$ \\
\hline \multirow{5}{*}{ S1 } & Igeo & 2.7 (M-HC) & -1.3 & 2.3 (M-HC) & 0.0 & $1.4(\mathrm{MC})$ & $3.8(\mathrm{HC})$ & $3.5(\mathrm{HC})$ \\
\hline & ER & 293.6 (HR) & 1.2 & 35.7 & 7.4 & 19.3 & 21.0 & 664.8 (VHR) \\
\hline & ICF & $2.6(\mathrm{MC})$ & 1.2 (MC) & 9.2 (VHC) & $1.3(\mathrm{MC})$ & 0.3 & 16.8 (VHC) & - \\
\hline & RAC & 32.0 (HR) & 0.0 & 4.0 & 29.0 (MR) & 0.0 & 64.6 (VHR) & - \\
\hline & ERF & 0.5 (MR) & 0.0 & 0.0 & 0.4 & 0.0 & 1.8 (HR) & - \\
\hline \multirow{5}{*}{ S2 } & Igeo $_{\text {ge }}$ & 2.1 (M-HC) & -2.0 & $2.0(\mathrm{MC})$ & -0.1 & 1.0 & $3.4(\mathrm{HC})$ & $1.5(\mathrm{MC})$ \\
\hline & ER & 189.0 (HR) & 0.7 & 30.1 & 6.9 & 15.2 & 16.0 & 172.4 (HR) \\
\hline & $\mathrm{ICF}$ & 0.0 & 2.1 (MC) & 24.7 (VHC) & $1.1(\mathrm{MC})$ & 0.9 & 63.0 (VHC) & - \\
\hline & RAC & 51.0 (VHR) & 1.7 & 7.4 & 32.4 (HR) & 2.7 & 70.4 (VHR) & - \\
\hline & ERF & 1.0 (MR) & 0.0 & 0.1 & 0.5 (MR) & 0.0 & 2.4 (HR) & - \\
\hline \multirow{5}{*}{ S3 } & Igeo & $2.9(\mathrm{M}-\mathrm{HC})$ & -1.4 & 2.4 (M-HC) & 0.2 & $1.5(\mathrm{MC})$ & $4.0(\mathrm{HC})$ & 3.0 (M-HC) \\
\hline & ER & 91.4 (CR) & 109.5 & 691.4 (VHR) & 310.2 (HR) & 688.5 (VHR) & $\begin{array}{l}1641.0 \\
\text { (VHR) }\end{array}$ & 29.1 \\
\hline & ICF & $2.1(\mathrm{MC})$ & $1.5(\mathrm{MC})$ & 12.9 (VHC) & 1.3 (MC) & 0.1 & 18.1 (VHC) & - \\
\hline & RAC & 35.5 (HR) & 0.0 & 1.5 & 30.9 (HR) & 0.0 & 61.4 (VHR) & - \\
\hline & ERF & 0.5 (MR) & 0.0 & 0.0 & 0.4 & 0.0 & 1.6 (HR) & - \\
\hline \multirow{5}{*}{ S4 } & Igeo & 2.9 (M-HC) & -1.2 & 2.5 (M-HC) & 0.2 & $1.6(\mathrm{MC})$ & $3.9(\mathrm{HC})$ & 2.3 (M-HC) \\
\hline & ER & 337.4 (VHR) & 1.3 & 41.3 (MR) & 8.7 & 22.0 & 22.9 & 301.0 (HR) \\
\hline & ICF & $1.6(\mathrm{MC})$ & $1.2(\mathrm{MC})$ & 12.7 (VHC) & $1.2(\mathrm{MC})$ & 0.1 & 16.0 (VHC) & - \\
\hline & RAC & 25.0 (MR) & 0.0 & 1.2 & 27.0 (MR) & 1.2 & 55.8 (VHR) & - \\
\hline & ERF & 0.3 & 0.0 & 0.0 & 0.4 & 0.0 & 1.3 (HR) & - \\
\hline \multirow{5}{*}{ S5 } & Igeo & 2.5 (M-HC) & -1.4 & 2.2 (M-HC) & 0.1 & $1.4(\mathrm{MC})$ & $3.8(\mathrm{HC})$ & 3.5 (HC) \\
\hline & ER & 251.4 (HR) & 1.1 & 34.0 & 7.9 & 19.3 & 20.7 & 684.4 (VHR) \\
\hline & ICF & $3.1(\mathrm{CC})$ & 1.5 (MC) & 17.4 (VHC) & $1.3(\mathrm{MC})$ & 0.2 & 28.6 (VHC) & - \\
\hline & RAC & 37.7 (HR) & 2.0 & 3.8 & 40.8 (HR) & 0.0 & 68.7 (VHR) & - \\
\hline & ERF & 0.6 (MR) & 0.0 & 0.0 & 0.7 (MR) & 0.0 & 2.2 (HR) & - \\
\hline \multirow{5}{*}{ S6 } & $I_{\text {geo }}$ & $3.3(\mathrm{HC})$ & -1.1 & 2.9 (M-HC) & 0.8 & $2.0(\mathrm{MC})$ & 4.2 (HC) & 3.5 (HC) \\
\hline & ER & 431.5 (VHR) & 1.4 & 54.6 (MR) & 13.3 & 29.6 & 27.1 & 692.7 (VHR) \\
\hline & ICF & 1.8 (MC) & 1.0 & 12.8 (VHC) & 1.1 (MC) & 0.1 & 14.4 (VHC) & - \\
\hline & RAC & 25.3 (MR) & 0.0 & 0.5 & 34.8 (HR) & 0.0 & 55.9 (VHR) & - \\
\hline & ERF & 0.3 & 0.0 & 0.0 & 0.5 (MR) & 0.0 & 1.3 (HR) & - \\
\hline \multirow{5}{*}{ S7 } & Igeo & $3.3(\mathrm{HC})$ & $\begin{array}{ll}-1.1 \\
\end{array}$ & 2.9 (M-HC) & 0.8 & $2.0(\mathrm{MC})$ & $4.2(\mathrm{HC})$ & $3.4(\mathrm{HC})$ \\
\hline & ER & 435.7 (VHR) & 1.4 & 56.1 (MR) & 12.9 & 29.4 & 27.2 & $627.2(\mathrm{VHR})$ \\
\hline & ICF & $2.2(\mathrm{MC})$ & $1.2(\mathrm{MC})$ & 13.9 (VHC) & $1.2(\mathrm{MC})$ & 0.2 & 16.7 (VHC) & - \\
\hline & RAC & 23.4 (MR) & 2.4 & 1.4 & 35.9 (HR) & 0.0 & 55.0 (VHR) & - \\
\hline & ERF & 0.3 & 0.0 & 0.0 & 0.6 (MR) & 0.0 & 1.2 (HR) & - \\
\hline
\end{tabular}

\section{Conclusions}

The analysis of total heavy metal concentrations and their chemical forms in sewage sludge is one of the most important issues in terms of assessment of the potential risk posed by these elements to the 
environment, and hence to living organisms. This is particularly important in regions of high heavy metal pollution. It has been found that concentrations of heavy metals examined in sewage sludge do not exceed the permissible norms in Poland and the EU, which is favorable in terms of agricultural use of sludge, and has a significant impact, both on the environment quality and human health. The analysis of sludge characteristics at different stages of processing revealed that biological processes and thickening of sewage sludge have a significant impact on heavy metal distribution, while anaerobic digestion and dehydration decrease the mobility of metals. The risk analysis conducted according to total and speciation indices showed that $\mathrm{Zn}, \mathrm{Cd}, \mathrm{Ni}$, and $\mathrm{Hg}$ posed the highest ecological risk, among the analyzed heavy metals. The comparison of values of different indices showed that when taking into account the chemical forms of heavy metals, in some cases they can be hazardous to the environment, and in some cases not. This can be seen when comparing the values of the Geoaccumulation Index ( $\left.\mathrm{I}_{\text {geo }}\right)$ and the Individual Contamination Factor (ICF) in relation to $\mathrm{Cr}, \mathrm{Ni}$, and $\mathrm{Pb}$. A similar relationship was observed for the values of the Potential Ecological Risk Factor (ER), Risk Assessment Code (RAC) and Ecological Risk Factor (ERF) in relation to $\mathrm{Zn}$ and Ni. The above findings confirmed that knowledge of the total concentrations of heavy metals allows only the sludge pollution level to be assessed whereas the mobility, bioavailability, and toxicity of these elements depend on the chemical forms in which they occur. Therefore, both total concentration and the chemical form of heavy metals in sewage sludge should be monitored and controlled regularly in order to identify potential hazards posed by these elements. This approach will allow for leading new regulations in this respect, which will contribute to the reduction of risk associated with secondary pollution of soils with heavy metals, as a result of their fertilization with sewage sludge. Moreover, it is also necessary to pay special attention to the need for the implementation of methods which allow for the removal of heavy metals at the very beginning of a WWTP's technological line, i.e., from raw wastewater. This could contribute to lowering the content of metals in sewage sludge.

Funding: This work was supported by the Ministry of Science and Higher Education. The research was carried out in the Institute of Environmental Engineering, Polish Academy of Sciences in Zabrze.

Conflicts of Interest: The author declares no conflicts of interest.

\section{References}

1. Zhang, X.; Wang, X.-Q.; Wang, D.-F. Immobilization of Heavy Metals in Sewage Sludge during Land Application Process in China: A Review. Sustainability 2017, 9, 2020. [CrossRef]

2. Turek, A.; Wieczorek, K.; Wolf, W.M. Digestion Procedure and Determination of Heavy Metals in Sewage Sludge-An Analytical Problem. Sustainability 2019, 11, 1753. [CrossRef]

3. Spanos, T.; Ene, A.; Styliani Patronidou, C.; Xatzixristou, C. Temporal variability of sewage sludge heavy metal content from Greek wastewater treatment plants. Ecol. Chem. Eng. S 2016, 23, 271-283. [CrossRef]

4. Feizi, M.; Jalali, M.; Renella, G. Assessment of nutrient and heavy metal content and speciation in sewage sludge from different locations in Iran. Nat. Hazards 2019, 95, 657-675. [CrossRef]

5. Tytła, M. The Effects of Ultrasonic Disintegration as a Function of Waste Activated Sludge Characteristics and Technical Conditions of Conducting the Process-Comprehensive Analysis. Int. J. Environ. Res. Public Health 2018, 15, 2311. [CrossRef]

6. Milieu Ltd. Environmental, Economic and Social Impacts of the Use of Sewage Sludge on Land. Final Report. Part II: Project Interim (DGENV.G.4/ETU/2008/0076r.). Final Report for the European Commission. Milieu Ltd., WRc, and RPA. DG Environment 2008. Available online: http://ec.europa.eu/environment/archives/ waste/sludge/pdf/part_ii_report.pdf (accessed on 29 April 2015).

7. Sánchez, C.H.; Gutiérrez, Á.; Galindo, J.M.; González-Weller, D.; Rubio, C.; Revert, C.; Burgos, A.; Hardisson, A. Heavy Metal Content in Sewage Sludge: A Management Strategy for an Ocean Island. Rev. Salud Ambient. 2017, 17, 3-9. Available online: http://www.ojs.diffundit.com/index.php/rsa/article/ viewFile/758/798 (accessed on 5 February 2019).

8. Tytła, M.; Widziewicz, K.; Zielewicz, Z. Heavy metals and its chemical speciation in sewage sludge at different stages of processing. Environ. Technol. 2016, 37, 899-908. [CrossRef] 
9. Duan, B.; Zhang, W.; Zheng, H.; Wu, C.; Zhang, Q.; Bu, Y. Comparison of Health Risk Assessments of Heavy Metals and As in Sewage Sludge from Wastewater Treatment Plants (WWTPs) for Adults and Children in the Urban District of Taiyuan, China. Int. J. Environ. Res. Public Health 2017, 14, 1194. [CrossRef]

10. Cantinho, P.; Matos, M.; Trancoso, M.A.; Correia dos Santos, M.M. Behaviour and fate of metals in urban wastewater treatment plants: A review. Int. J. Environ. Sci. Technol. 2016, 13, 359-386. [CrossRef]

11. Duan, B.; Zhang, W.; Zheng, H.; Wu, C.; Zhang, Q.; Bu, Y. Disposal Situation of Sewage Sludge from Municipal Wastewater Treatment Plants (WWTPs) and Assessment of the Ecological Risk of Heavy Metals for Its Land Use in Shanxi, China. Int. J. Environ. Res. Public Health 2018, 14, 823. [CrossRef]

12. Milik, J.K.; Pasela, R.; Lachowicz, M.; Chalamoński, M. The concentration of trace elements in sewage sludge from wastewater treatment plant in Gniewino. JEE 2017, 18, 118-124. [CrossRef]

13. Rizzardini, C.B.; Goi, D. Sustainability of domestic sewage sludge disposal. Sustainability 2014, 6, $2424-2434$. [CrossRef]

14. Gawdzik, J. Mobilność Wybranych Metali Ciężkich w Osadach Ściekowych (Mobility of Selected Heavy Metals in Sewage Sludge), 1st ed.; Monographs, Studies, Dissertations (M44); Kielce University of Technology: Kielce, Poland, 2013; pp. 37-46.

15. Regulation of the Minister of Environment of 13th July 2010 on the Municipal Sewage Sludge (J. L. 2010, No. 137, Item. 924). Available online: http://prawo.sejm.gov.pl/isap.nsf/download.xsp/WDU20101370924/O/ D20100924.pdf (accessed on 29 June 2019).

16. Council Directive of 12th June 1986 on the Protection of the Environment, and in Particular of the Soil, When Sewage Sludge Is Used in Agriculture (86/278/EEC). Available online: https://eur-lex.europa.eu/legalcontent/PL/TXT/PDF/?uri=CELEX:31986L0278\&from=EN (accessed on 12 June 1986).

17. Yang, T.; Huang, H.; Lai, F. Pollution hazards of heavy metals in sewage sludge from four wastewater treatment plants in Nanchang, China. Trans. Nonferrous Met. Soc. China 2017, 27, 2249-2259. [CrossRef]

18. Karwowska, B.; Dabrowska, L. Bioavailability of heavy metals in the municipal sewage sludge. Ecol. Chem. Eng. 2017, 24, 75-86. [CrossRef]

19. Ure, A.M.; Quevauviller, P.; Mantau, H.; Griepink, B. Speciation of heavy metals in soils and sediments. An account of the improvement and harmonization of extraction techniques undertaken under the auspices of the BRC of the Commission of the European Communities. Int. J. Environ. Anal. Chem. 1993, 51, 135-151. [CrossRef]

20. Álvarez, E.A.; Callejón Mochón, M.; Jiménez Sánchez, J.C.; Ternero Rodríguez, M. Heavy metal extractable forms in sludge from wastewater treatment plants. Chemosphere 2002, 47, 765-775. [CrossRef]

21. Gusiatin, Z.M.; Kulikowska, D.; Klik, B.K.; Hajdukiewicz, K. Ecological risk assessment of sewage sludge from municipal wastewater treatment plants: A case study. J. Environ. Sci. Health A Tox Hazard. Subst. Environ. Eng. 2018, 53, 1167-1176. [CrossRef] [PubMed]

22. Tessier, A.; Campbell, P.G.C.; Bisson, M. Sequential extraction procedure for the speciation of particulate trace metals. Anal. Chem. 1979, 51, 844-851. [CrossRef]

23. Zhao, S.; Feng, C.; Yang, Y.; Niu, J.; Shen, Z. Risk assessment of sedimentary metals in the Yangtze Estuary: New evidence of the relationships between two typical index methods. J. Hazard. Mater. 2012, 241-242, 164-172. [CrossRef]

24. Müller, G. Index of geoaccumulation in sediments of the Rhine River. Geo J. 1969, 2, 108-118.

25. Hakanson, L. Ecological risk index for aquatic pollution control, a sedimentological approach. Water Res. 1980, 14, 975-1001. [CrossRef]

26. Ikem, A.; Egiebor, N.O.; Nyavor, K. Trace elements in water fish and sediment from Tuskegee Lake, Southeastern USA. Water Air Soil Pollut. 2003, 149, 51-75. [CrossRef]

27. Perin, G.; Craboledda, L.; Lucchese, M.; Cirillo, R.; Dotta, L.; Zanette, M.L.; Orio, A.A. Heavy metal speciation in the sediments of Northern Adriatic Sea-A new approach for environmental toxicity determination. In Heavy Metal in the Environment 2; Lakkas, T.D., Ed.; CEP Consultants Limited: Edinburgh, Scotland, 1985; pp. 454-456.

28. Saleem, M.; Iqbal, J.; Shah, M.H. Geochemical speciation, anthropogenic contamination, risk assessment and source identification of selected metals in fresh water sediments-A case study from Mangla Lake, Pakistan. Environ. Nano Monit. Manag. 2015, 4, 27-36. [CrossRef]

29. Mamut, A.; Eziz, M.; Mohammad, A. Pollution and Ecological Risk Assessment of Heavy Metals in Farmland Soils in Yanqi County, Xinjiang, Northwest China. Eurasian Soil Sci. 2018, 51, 985-993. [CrossRef] 
30. Baran, A.; Tarnawski, M.; Koniarz, T. Spatial distribution of trace elements and ecotoxicity of bottom sediments in Rybnik reservoir, Silesian-Poland. ESPR 2016, 23, 17255-17268. [CrossRef] [PubMed]

31. Tytła, M.; Kostecki, M. Ecological risk assessment of metals and metalloid in bottom sediments of water reservoir located in the key anthropogenic "hot spot" area (Poland). Environ. Earth Sci. 2019, 78, 179. [CrossRef]

32. Central Statistical Office (CSO). Sludge Produced during the Year 2017 (Tables), Warsaw, Poland 2017. Available online: https://stat.gov.pl/ (accessed on 23 May 2019).

33. Google Maps. Available online: https://www.google.pl/maps/@52.0122001,29.5346949,3.17z/data=!5m1!1e4? hl=en (accessed on 29 May 2019).

34. Google Maps. Available online: https://www.google.pl/maps/@50.3650717,18.80662,12z/data=!5m1!1e4?hl= enfgg (accessed on 29 May 2019).

35. European Pollutant Release and Transfer Register (E-PRTR). Available online: https://prtr.eea.europa.eu/\#/ industrialactivity (accessed on 29 May 2019).

36. Polish Committee for Standardization. Characteristics of Sewage Sludge, Determination of Dry Residue and Water Content; PN-EN 12880:2004; Polish Committee for Standardization: Warszawa, Poland, 2004.

37. Polish Committee for Standardization. Characteristics of Sewage Sludge, Determination of Loss on Ignition of Dry Matter; PN-EN 12879:2004; Polish Committee for Standardization: Warszawa, Poland, 2004.

38. Kabata-Pendias, A. Trace Elements in Soils and Plants, 4th ed.; Taylor \& Francis: London, UK, 2011; pp. 41-42.

39. Kacprzak, M.; Neczaj, E.; Fijałkowski, K.; Grobelak, A.; Grosser, A.; Worwag, M.; Rorat, A.; Brattebo, H.; Almas, A.; Singh, B.R. Sewage sludge disposal strategies for sustainable development. Environ. Res. 2017, 156, 39-46. [CrossRef] [PubMed]

40. Ji, L.; Luo, G.; Gao, J.; Yuan, S.; Du, J.; Wang, Z. Quantitative evaluation of potential ecological risk of heavy metals in sewage sludge from three wastewater treatment plants in the main urban area of Wuxi, China. Chem. Ecol. 2015, 31, 235-251. [CrossRef]

41. Tiruneh, A.T.; Fadiran, A.O.; Mtshali, J.S. Evaluation of the risk of heavy metals in sewage sludge intended for agricultural application in Swaziland. Int. J. Environ. Sci. Technol. 2014, 5, 197-216. [CrossRef]

42. Tytła, M.; Widziewicz, K. The influence of sewage sludge processing in wastewater treatment plant on the heavy metals contents. ACEE 2013, 6, 43-48.

43. Fuentes, A.; Llorens, M.; Saez, J.; Soler, A.; Aguilar, M.I.; Ortuno, J.F.; Meseguer, V.F. Simple and sequential extractions of heavy metals from different sewage sludges. Chemosphere 2004, 54, 1039-1047. [CrossRef] [PubMed]

44. Wang, C.; Li, X.-C.; Ma, H.-T.; Qian, J.; Zhai, J.-B. Distribution of extractable fractions of heavy metals in sludge during the wastewater treatment process. J. Hazard. Mater. 2006, 137, 1277-1283. [CrossRef] [PubMed]

45. Merrington, G.; Oliver, I.; Smernik, R.J.; McLaughlin, M.J. The influence of sewage sludge properties on sludge-borne metal availability. Adv. Environ. Res. 2003, 8, 21-36. [CrossRef]

46. Milik, J.; Pasela, R.; Szymczak, M.; Chalamoński, M. Evaluation of the Physico-chemical Composition of Sludge from Municipal Sewage Treatment Plant. Ann. Set Environ. Prot. 2016, 18, 579-590.

47. Gomes, J.; Matos, A.; Quinta-Ferreira, R.M.; Martins, R.C. Environmentally applications of invasive bivalves for water and wastewater decontamination. Sci. Total Environ. 2018, 630, 1016-1027. [CrossRef] [PubMed]

48. Rosa, I.C.; Costa, R.; Gonçalves, F.; Pereira, J.L. Bioremediation of metal-rich effluents: Could the invasive bivalve Corbicula fluminea work as a biofilter? J. Environ. Qual. 2014, 43, 1536-1545. [CrossRef] [PubMed]

49. Magni, S.; Parolini, M.; Soave, C.; Marazzi, F.; Mezzanotte, V.; Binelli, A. Removal of metallic elements from real wastewater using zebra mussel bio-filtration process. J. Environ. Chem. Eng. 2015, 3, 915-921. [CrossRef]

(C) 2019 by the author. Licensee MDPI, Basel, Switzerland. This article is an open access article distributed under the terms and conditions of the Creative Commons Attribution (CC BY) license (http://creativecommons.org/licenses/by/4.0/). 